\title{
ON THREE NEW SPECIES OF EUCALYPTUS.
}

By R. T. Baker, F.L.S., Curator, Technological Museum, SYDNEY.

(Plates XLIII.-XI.V.)

Eucalyptus oreades, sp.nov.

\section{A "Mountain Ash."}

\section{(Plate xliii.)}

A tall tree with a smooth whitish bark down to the ground, or sometimes leaving a lighter rough bark 6-8 feet from the ground.

Young leaves thin, elliptical-oval, shortly acuminate on a petiole of about an inch or more; venation more distinct than on mature leaves. Mature leaves long, often 9 inches, thick, shining, dark green on both sides, on rather long petioles, lanceolate, falcate, venation distinct, intramarginal vein removed from the edge, lateral veins very oblique, often approaching the venation of E. coriacea, A. Cunn. Oil glands numerous.

Peduncles axillary not numerous, generally with about 6-8 flowers. Calyx-tube hemispherical, on a pedicel of about 2-3 lines. Operculum hemispherical, acuminate, about the size of the calyx. Stamens recurved in the bud; all fertile. Anthers kidney-shaped. Ovary small, flat-topped

Fruit hemispherical, rarely pyriform, about 3 lines in diameter, the rim thin, capsule sunk, valves rarely or scarcely exserted.

Hab.-Lawson (H. G. Smith and L.T.B.); Mount Victoria and road to Jenolan Cares (R. H. Cambage).

This tree is allied to $E$. Sieberiana, F.v.M., in the venation and shape of the leaves and nature of timber, but it differs from it in its smooth bark and shape of fruits. 
When seen in its native habitat it might easily be passed by as $E$. saliyna, Sm., but it differs from that species in the timber, fruits and chemical constituents of its oil, and venation of the leaves.

In the venation of the leaves it might also be classified with $E$. dives, Schau., but in no other feature does it approach that species.

The fruits are somewhat similar to those of E. stricta, Sieb., E. obtusifora, and E. fraxinoides, but smaller.

The venation and timber, as well as fruits and flowers, differentiate it from E. coriacea, A. Cunn., although some of its chemical constituents connect it with that species.

In botanical sequence it is placed between E. Sieberiana, F.v.M., and E. coriacea, A. Cunn.

This tree so far has only been found at the heads of gullies on the Blue Mountains, at the foot of precipitous sandstone cliffs, and always near the foot of waterfalls on the edge of the pools. It grows very tall, with scarcely a branch till near the top or head, which generally appears above the top of the smaller gullies.

It very possibly has been looked upon or classed as $E$. saligna, Sm., which is sometimes found on the banks of streams near the coast, both having a similar silver-grey shining bark.

If it were not for the fruit and buds it might be regarded as a smooth-barked variety of E. Sieberima, F.v.M. ; but this cortical variation has now been shown to have very little to support it in the field, taken in conjunction with other features.

Timber.-A light pale-coloured, rather soft timber, fissile, and not easily distinguished from that of E. Sieberiana, F.v.M. ("Mountain Ash"); it should be classified amongst the "Ashes." It is quite a distinct timber from "Blue Gum," $E$. salimia, and it is only suitable for indoor work. As its specific gravity is light and the timber tough it might be tried as a substitute for English Willow. It is largely used in the saw mills on Mount Victoria, towards Jenolan (R. H. Cambage). 
0il. - Oil distilled from fresh leaves averaged $1 \cdot 16$ per cent. The crude oil is only slightly coloured yellowish in tint; the rectified oil is almost colourless. The specific gravity of crude oil was 8869 at $15^{\circ} \mathrm{C}$, whilst the specific gravity of rectified oil below $190^{\circ}$ was 8646 at $15^{\circ}$ C. Sp. gr. fraction $240-275,9$ per cent. $=9377$ at $15^{\circ} \mathrm{C}$. Specific rotation crude oil $[\mathrm{a}] \mathrm{D}-25 \cdot 6^{\circ}$. Specific rotation large fraction $[\mathrm{a}] \mathrm{D}-35 \cdot 7^{\circ}$.

A large quantity of phellandrene was present. No eucalyptol could be detected.

On rectification 83 per cent. distilled below $190^{\circ}$ C., 4 per cent. below $240^{\circ} \mathrm{C}$., and 9 per cent. below $275^{\circ} \mathrm{C}$.

The third fraction contains a small quantity of eudesmol determined by crystallisation. It does not appear to contain in any extent the constituent which gives to the oils of E. Sieberiana, F.v.M., E. coriacea, A. Cunn., E. dives, Schau, their characteristic odour (H. G. Smith).

Kino.-The exudation kino of this tree is tough, astringent, and contains no gum, eudesmin or aromadendron. The tannin gives a blue-purple colour, with ferric chloride in dilute aqueous solution, and a blue-purple colour and a dark precipitate at once with a solution of iron alum (H. G. Smith).

\section{E. MACULOSA, sp.nov.}

\section{"Spotted Gum."}

\section{(Plate xliv.)}

A tree rarely exceeding 60 feet in height, usually from 20-40 feet (W.B.). Bark smooth to the ground.

Young leaves lanceolate, 2 or 3 inches long, opposite, very narrow. Mature leaves narrow, lanceolate, falcate, not shining, same colour on both sides, venation obscure, intramarginal vein close to the edge, lateral veins oblique. Some trees have the leaves quite rigid and erect. 
Peduncles axillary, slender, under 6 lines long, bearing from 4-16, occasionally 20, sessile or shortly pedicellate flowers. Calyx turbinate, about 1 line long; operculum of equal length, obtuse. Stamens all fertile, short and incurved, the free end appearing pendulous in the bud, as shown in the plate. Anthers small, ovoid, opening by longitudinal slits, connective prominent. Ovary flat-topped.

Fruit in the early stage much resembles that of E. homastoma, var. micrantha, and probably this species has been placed in the past under that variety. In the mature stage the fruit is turbinate, and resembles some forms of E. Smithii, R.T.B., about 2 lines in diameter, rim domed, valves exserted, obtuse.

IAab._Bungendore (W. Bäuerlen); Charley's Forest, Braidwood (II. Bäuerlen).

It grows in poor open forest ground up to 50 to 60 feet in height, and from 1 to 3 feet in diameter, with a rather dense head. Some trees on the ridges have the appearance in the distance of Pines, hence it is sometimes called "Pine." In a shrubby form it flowers when only 4 or 5 feet high. The bark is of different shades of grey, or bluish or yellow, with spots of about the same size and shape as those of E. maculata, Hook., the true "Spotted Gum." The hark is smooth to the ground (W. Bäuerlen).

This species has probably in the past (as stated above) been confounded with $E$. hremastoma, Sm., var. micrantha, Benth., (vide Eucalyptographia, Dec. ii, E. hcemastoma, Sm., "Spotted Gum"). It differs, however, from that species and its variety in the shape of mature fruits, venation of leaves, in all the stamens being fertile, in the anthers being parallel, and especially in the chemical constituents of the oil. The bark of this species is always more bluish and less glossy than E. hamastoma, Sm. The two trees are often associated (W.B.).

It has affinity with E. Smithii in the fruits in some instances, and particularly in the chemical composition of its oil. With the original "Spotted Gum," E. maculata, Hook., it has little or no affinity. 
On account of the markings on the bark it could with equal justice be called Spotted Gum as E. maculata, but to distinguish it from that species and to record its field character the name of $E$. maculosa is proposed. The two species, however, are never found together in the same locality (W. Bäuerlen).

From the nature of the timber, bark, shape of buds and fruits, venation of leaves, this species is placed tentatively after $E$. viminalis, Labill.

Its chemical constituents connect it with E. Smithii, R.T.B.

Under this species it may be mentioned that two other trees are known by the same vernacular as this tree, viz. :-

(1) "Spotted Gum," at Charley's Forest and Fagan's Creek, Braidwood (W.B.).

(2) "Spotted Gum," at Ilford (R.T.B.).

The chemical and botanical evidence points, as far as yet examined, to these being distinct from the "Spotted Gum " of Bungendore, but in the meantime they are placed here tentatively as var. A. and var. B. of this species.

Var. A. is at certain seasons the host of a Psyllid, producing a beautifully figured, yellow-coloured lerp.

Var. B., when wounded, exudes a whitish substance called by the settlers "butter-milk" (G. Harris).

Timber. - The timber of the Bungendore specimens closely resembles that of the so-called E. Gunnii, Hook., occurring on the Snowy Mountains of this Colony, but is a little harder. It is straight-grained, free and easy to work, seasons badly, and is generally depreciated in value by the presence of gum-veins. It is a poor commercial timber. The timbers of the varieties $\mathrm{A}$ and $\mathrm{B}$ are similar in texture, but superior in hardness to the type, but nevertheless cannot be recommended for commercial use.

0il.-The crude oil is a light amber colour. The yield of oil from fresh leaves gave 1.06 per cent, a mean of three distillations. The rectified oil is of a light yellowish tint, and in odour, taste, ic., resembles rectified Eucalyptus oils of the better class. 
It contains no phellandrene, but a small quantity of dextrorotatory pinene is present. The rectified oil (fraction representing 87 per cent. of crude oil) contained $45 \cdot 5$ per cent. eucalyptol, rather less than should be demanded in a good Eucalyptus oil, as myself and colleague have suggested 48 per cent. of eucalyptol as the minimum allowable in oils used medicinally (see recommendations by the New South Wales committee appointed to deal with the addendum to the British Pharmacopœia). The specific gravity of the crude oil at $15^{\circ} \mathrm{C} .=\cdot 9858$. The specific gravity of the rectified oil at $15^{\circ} \mathrm{C} .=9075$. The specific rotation of the crude oil $=[\mathrm{a}] \mathrm{D}+3 \cdot 66$. The specific rotation of the rectified $\mathrm{oll}=[\mathrm{a}] \mathrm{D}+3 \cdot 31 ; 92$ per cent. of the crude oil distilled below $185^{\circ}$ C. (H. G. Smith).

Mr. W. Bäuerlen, who is familiar with E. hamastoma, Sm., and E. maculosa in the field, states "that there can be no doubt about their being distinct species, although there is so much similarity in the leaves and sometimes also in the general aspect that sometimes under certain conditions it is rather difficult to distinguish them. On comparison, however, one finds buds and fruits quite different, so much so that I only need speak of the trees as they appear in the field under certain conditions. Under such conditions E. hamastoma, Sm., is all round the larger of the two, attaining a diameter of 2-5 feet, sometimes the butt bulging enormously near the ground; if anything it is more crooked than E. maculosa usually is, the trunk not being by far so spotted as E. maculosa, and always quite different in colour; this holds invariably from the youngest saplings, or even seedlings, to the oldest trees. The trunks of E. maculosa are always bluish with dark grey spots, or sometimes reddish or greenish spots, and always dull coloured, while the trunks of $E$. hcemastoma are always of a creamy colour, often, especially in the limbs, approaching quite white, but not dull or chalky; they have the appearance as if they were rubbed over with soap.

"Both trees are smooth to the very ground, but the difference of colour on the trunk never misled me in one instance. The foliage of E. maculosa is always more bluish, and the leaves more 39 
drooping; the veining is more conspicuous in the leaves of this: species, and the leaves in the young state are narrower than the leaves in general, although there is very little difference.

"In some localities, like the steep, stony hillside near Lake George, it is more difficult to distinguish the two trees, especially when young; there E. homastoma has a very dense head with very narrow leaves, and also somewhat bluish in colour, but the trunks have their respective blue or creamy colour, and after a little experience one soon distinguishes the trees by that, if by nothing else. E. maculosa never has the insect markings. (scribbles) so persistently found on E. hcemastoma."

\section{Eucalyptus patentinervis, sp.nov.}

\section{"Bastard Mahogany."}

\section{(Plate xlv.)}

A medium-sized tree as far as seen, with a stringy bark similar to that of E. resinifera, Sm. Ultimate branchlets angular.

Young leaves ovate, shortly acuminate, lanceolate, thin, almost membranous, petiole slender, from 1 to 2 inches long, venation prominent, intramarginal vein removed from the edge. Mature leaves lanceolate-falcate, coriaceous, acuminate, almost a foot long in some cases, not shining, colour uniform on both sides, petiole rather slender, channelled above, venation very distinct in the coast trees but finer in the inland ones, lateral veins very prominent and spreading, curved, numerous, the intramarginal vein removed from the edge. Oil glands very numerous.

Peduncles axillary, about 1 inch long, flattened, bearing about 10 fairly large flowers. Calyx occasionally angular, 6 lines long. Operculum about as long as the calyx, conical, sometimes concave below the summit. Stamens long, inflexed in the bud, all fertile. Anthers parallel. Ovary dome-topped.

Fruits large, hemispherical to pyriform, on a pedicel of about 4 lines, 5 lines in diameter, rim quite 1 line broad; valves prominently exserted, acute, nearly 3 lines long. 


\section{Hab.-Ballina (W. Bäuerlen); Bungwall (A. Rudder).}

At Ballina this tree is found on poor sandy soil associated with E. tereticornis, Sm., and E. corymbosa, Sm., whilst at Bungwall it occurs on low clayey soil. It grows to a fairly large size, but always crooked, with a stem diameter from 2 to 3 feet, but soon branching, the limbs long and stout, gnarled and crooked; clear trunk about 10 feet in height (W. Bäuerlen). The bark is fibrous, though not so fibrous as in the true "Stringybark," but resembling that of $E$. resinifera, Sm., more than any other, and extending right out to the branchlets, or nearly so.

Timber.-Not used, apparently worthless (W. B.).

The common name of "Bastard Mahogany" might lead one to place it under $E$. resinifera, Sm., and no doubt it may have been classed in herbaria with that species, but it is certainly distinct from it. The leaves of E. resinifera have "numerous fine, close, parallel and almost transverse veins, sometimes scarcely conspicuous, the intramarginal one close to the edge." This species has more the venation of $E$. tereticornis, Sm. The transverse veins are oblique and prominent, and the intramarginal one removed from the edge, particularly so in the young leaves. The venation, therefore, shows no connection with E. resinifera, Sm., nor does it with E. pellita, F.v.M. From this latter species it also differs in the shape and size of the calyx-tube, and also in the fruits. The only connection apparently with $E$. resinifera is in the bark. The timber does not appear to have the reputation for quality similar to that of $E$, resinifera.

According to F. v. Mueller, E. pellita, F.v.M., is closely connected with $E$. botryoides and also E. saligna, but this species has quite a distinct venation from any of these; in fact, it would be difficult to connect it with them.

Mr. Bäuerlen has observed in the field that the base of the stamens is always coloured red.

In botanical sequence it is placed between E. tereticornis, Sm., and E. rudis, Endl. 


\section{EXPLANATION OF PLATES.}

Plate xliii.-E. oreades.

Fig. 1.-Young leaf.

Fig. 2.-Terminal branchlet with early buds.

Fig. 3.-Twig with mature leaf, leaves and buds.

Fig. 4.-Mature leaf.

Fig. 5. - Section of bud
Fig. 6.-Anther (back and front view) ? enlarged.

Figs. 7-9.-Fruits.

\section{Plate xliv.-E. maculosa.}

Fig. 1.-Sucker-leaves from Bungendore.

Fig. 2.-Twigs with flowers and buds.

Fig. 3.-Section of bud
Fig. 4.-Anther (back and front view)

Figs. 5-6.-Fruits.

$$
\text { Plate xlv.-E. patentinervis. }
$$

Fig. 1.-Sucker or young leaf.

Fig. 2--Mature leaves and twig, with buds and flower.

Fig. 3.-Early buds.

Fig. 4.-Section of bud showing ovary

Fig. 5.-Anther (back and front view

Figs. 6-7.--Fruits. 


\section{$2 \mathrm{BHL}$ Biodiversity Heritage Library}

Baker, Richard T. 1900. "On three new species of Eucalyptus." Proceedings of the Linnean Society of New South Wales 24, 596-604.

https://doi.org/10.5962/bhl.part.7684.

View This Item Online: https://www.biodiversitylibrary.org/item/21735

DOI: https://doi.org/10.5962/bhl.part.7684

Permalink: https://www.biodiversitylibrary.org/partpdf/7684

\section{Holding Institution}

MBLWHOI Library

Sponsored by

MBLWHOI Library

\section{Copyright \& Reuse}

Copyright Status: NOT_IN_COPYRIGHT

This document was created from content at the Biodiversity Heritage Library, the world's largest open access digital library for biodiversity literature and archives. Visit BHL at https://www.biodiversitylibrary.org. 